\title{
VISUAL SELECTION IN THE LAND SNAIL ARIANTA ARBUSTORUM
}

\author{
DAVID T. PARKIN * \\ Department of Zoology, University of Manchester, Manchester 13, England
}

Received 16.ii.70

\section{INTRODUGTION}

DURING the last twenty years there have been considerable advances in the understanding of the ecological genetics of polymorphic land snails. Cain and Sheppard (1950) were the first to show systematic patterns in the distribution of the colour and banding morphs of Cepaea nemoralis L., and considered that these could not be ascribed to random factors such as genetic drift or the founder effect. They suggested that predators were exerting visual selection which resulted in populations of $C$. nemoralis matching the background of the habitat in which the snails were living. Further work by these authors (1952, 1954) and by Sheppard (1951, 1952) showed that Song Thrushes (Turdus ericetorum Turton) were the agents mainly responsible for this selection. Subsequent workers have provided further examples of visual selection in populations of land snails from other areas of England (e.g. Currey, Arnold and Carter, 1964; Arnold, 1965; Greenwood, in prep.). Goodhard (1958), (1962), Carter (1965) and Cameron (1968) established that similar effects occur among populations of Cepaea hortensis Mull.

These two species have a complex series of loci controlling the shellcharacter polymorphism, and consequently the analysis of the selective forces acting upon these loci is difficult. A less complex species might facilitate the separation of the interactions between visual selection and other selective forces such as climate.

An example of such a species is the European gastropod Arianta arbustorum L. This paper, which is the first of a series, examines the variation in natural populations of Arianta, and reports upon the results of a survey undertaken to examine the effects of predation upon some populations of the species in Derbyshire, England.

\section{Material AND MEthods}

\section{(a) Arianta arbustorum}

A. arbustorum is a polymorphic helicid, approximately $20 \mathrm{~mm}$. in diameter. Its genetics have been studied by Oldham (1934) and Cook and King (1966) from whom the following data are taken. It appears to be dimorphic for colour, yellow being recessive to brown. The condition "yellow" is not caused by the presence of a yellow pigment as in Cepaea, but is the consequence of the absence of brown pigment. It is therefore similar to the variety albina of Helix aspersa L. (Taylor, 1914) and perhaps to "yellow-white" in C. nemoralis (Cain, Sheppard and King, 1968).

There is only one band, which is in the position 3 of von Martens (see Cain and Sheppard, 1950). Presence of the band is dominant to its absence.

* Present address : Department of Zoology, West Mains Road, Edinburgh 9, Scotland. 
The banding locus is closely linked to that controlling shell pigmentation, and Cook and King (1966) estimated a recombination frequency of 0.7 per cent. Thus, colour and banding genes tend to be inherited as a supergene.

The shell of $A$. arbustorum is typically mottled with whitish flecks; this condition being dominant to unmottled. The flecks are formed by small opaque patches lacking pigment, and the thin periostracum gives them a characteristic yellow tint. On a yellow snail, the shell is translucent between the flecks, and the animal appears more uniformly coloured than does a brown which is patterned with pale straw-coloured flecks on a darker background. In the region covered by this study, unmottled individuals were very rare $(<0 \cdot 1$ per cent.) and the character is not included in the analysis which follows.

\section{(b) The area of the survey}

Carboniferous limestone in the counties of Derbyshire and Staffordshire in Northern England extends from Castleton in the north to Ashbourne in the south: a distance of approximately 22 miles. For most of its length this region is 8 or 9 miles wide. It is dissected by several major rivers, and their many tributary streams, which run typically in steep valleys, often with limestone outcrops and cliffs. These valleys are known as the Derbyshire Dales.

The rainfall is high in this part of England. The annual figure for Buxton (in the west) is 48.4 inches, at Chatsworth, less than 12 miles east, it is 32.6 inches. This represents a drop of almost a third over a few miles. There are also sharp differences in rainfall between the high, exposed surfaces and the sheltered valleys close at hand.

The steep slopes and thin soil allow rapid drainage, which prevents leaching on the sides of the valleys. On the flat areas above the dales, the soil is deeper, drainage is slower, and some leaching takes place. On some parts of the flat tops the removal of calcium carbonate and the accumulation of non-calcareous clay residue gives a heavy brown soil several inches thick. This forms permanent pasture and is unsuitable for Arianta and Cepaea. These snails are only found in the valleys and the present paper deals with populations found along the rivers Wye and Derwent.

\section{(c) The Wye Valley}

The river Wye flows across the limestone massif in Derbyshire from west to east (see fig. 1). It thus flows down the gradient of precipitation. As there are changes in the morph-frequencies of $A$. arbustorum which appear to be associated with rainfall (Parkin, in prep.), it is necessary to divide the valley up into units sufficiently small to be exposed to approximately the same major climatic conditions. The Wye valley between Buxton and Bakewell has already been divided by popular use into four approximately equal units, and these are used in the ensuing analysis. The subunits are from west to east: Wyedale, Cheedale, Millersdale and Monsaldale, and are shown in fig. 1.

The habitats which occur fall into six major types, in one of whichbroken stone and scree-Arianta was only found on three occasions, with fewer than five shells in each. The remaining five habitats are described below.

Short Grass. Limestone turf not more than $12 \mathrm{~cm}$. high, in which the majority of the vegetation is grass. This usually occurs on the exposed, 


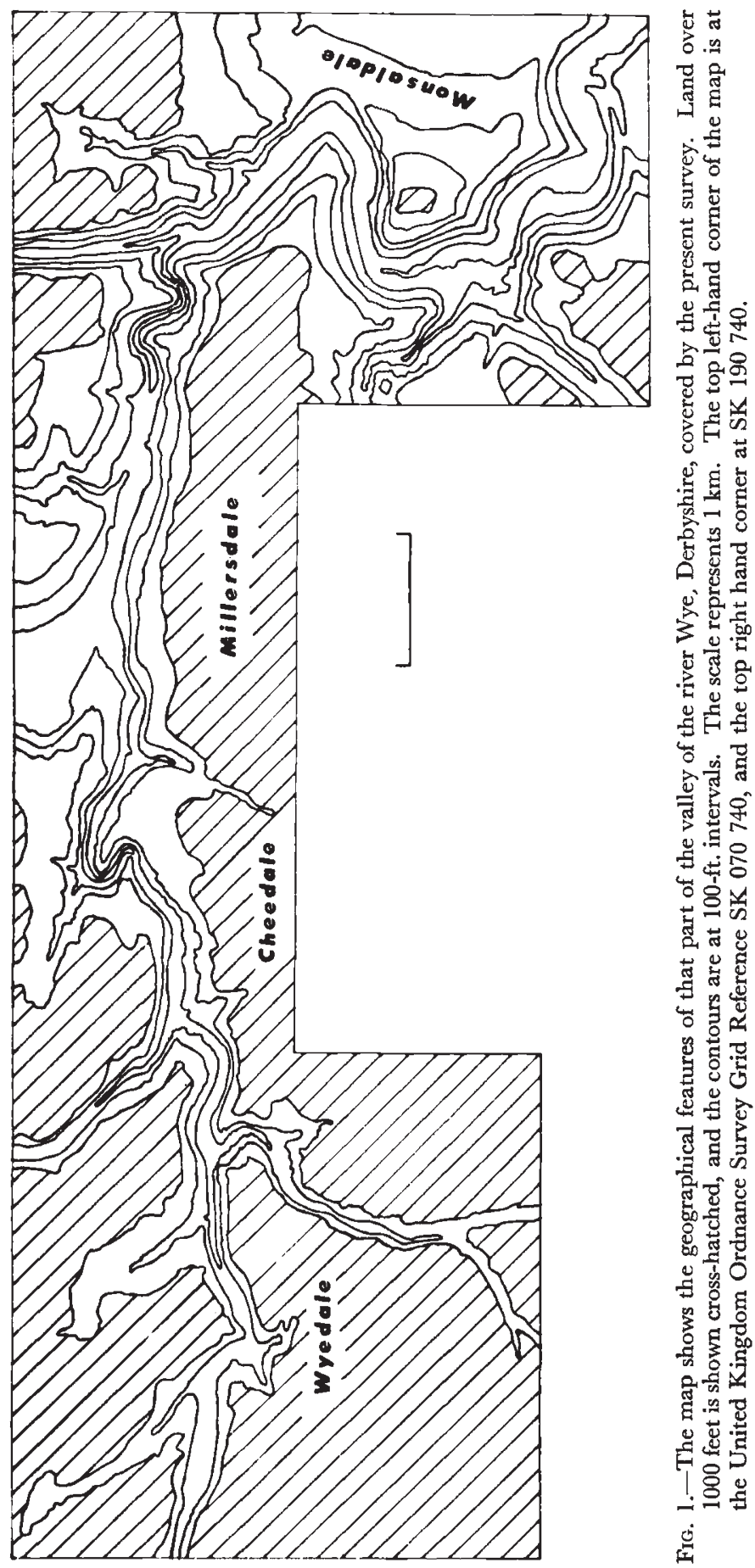


well-drained southwards-facing sides of the valleys, or on high sides around rocky outcrops. In general, this is not a favourable habitat for Arianta, and most samples contain only $C$. nemoralis, with occasional Helicigona lapicida $\mathrm{L}$.

Long Grass. This habitat grades continuously with the next, but is defined as containing mostly grass (not less than $12 \mathrm{~cm}$. high) with only a few isolated dicotyledons. It usually occurs on the more shady northwardsfacing slopes, but in the west, where rainfall is high, the south-facing sides also support this habitat.

Mixed Herbage. This term covers any habitat with vegetation more than $12 \mathrm{~cm}$. high and containing a predominantly mixed flora. Included are stands of vegetation such as brambles (Rubus sp.), Coltsfoot (Tussilago farfara L.), and Dog's Mercury (Mercurialis perennis L.).

Tall Herbage. In the bottom of valleys or on patches of level ground where the soil is thin and stony, nettles (Urtica dioica L.) and Willowherb (Epilobium sp.) grow in a highly characteristic way. The stems are at least $30 \mathrm{~cm}$. high and straight with the leaves clustered at the top, and each plant stands an inch or two clear of its neighbour.

Woods. In the west, the woods are dark and gloomy. The understorey is frequently Dog's Mercury or scattered nettles and moss, with frequent areas of bare earth, stones and leaf litter from the previous season. Ash (Fraxinus excelsior L.) predominates, with some Sycamore (Acer pseudoplatanus L.). Further to the east, the trees become more scattered with grass underneath, and the species are replaced by Oak (Quercus sp.), with Hawthorn (Crataegus monogyna Jacq.) and Hazel (Corylus avellana L.) scrub along the edges of the woods, even on north-facing sides.

\section{(d) Methods}

Random samples were taken from small areas (with maximum diameters of about 30 metres) to ensure that each represented a homogeneous population. This upper limit of area was chosen because Arianta is similar in size to Cepaea, and because the panmictic unit in the latter species is believed to be about 30 metres in diameter (Lamotte, 1951; Murray, 1962).

The Arianta were scored for colour and banding. If the lip of the shell was fully formed, the animal was regarded as being adult, otherwise as juvenile. When a shell was broken, only pieces which were the major part of an individual were used in the analysis; fragments were discarded. Samples which contained five or more scorable individuals of $A$. arbustorum are included in this paper. This restriction excludes all samples taken from short and long grasslands in Cheedale and Monsaldale from the paper.

\section{(e) Variation in brown}

There is a considerable amount of variation in the amount of pigment in brown shells, resulting in a gradation from very pale, almost straw-coloured, individuals with only a trace of pigment behind the lip, to those coloured a rich dark purplish brown. The brown Arianta have therefore been divided into two categories: pale individuals (called "buff") and dark brown (" chocolate"). There is inevitably a certain amount of subjectivity here, as the two categories are not discontinuous. However, scoring was found to be repeatable to within 1 or 2 per cent.

The data from the samples of Arianta are presented in table 1. Table 2 
TABLE 1

The data from the samples of Arianta arbustorum (which contained five or more individuals which could be scored for colour and banding) collected in the valley of the river Wye

Column 1 gives the reference number of the sample which is shown in fig. 1 , and Column 2 shows the National Grid Reference of the sampling point within square SK. Column 3 indicates the habitat from which the sample was taken. Columns 4-9 give the number of individuals in the six phenotype classes: yellow, buff and chocolate, unbanded and banded. Columns 10 and 11 show the total number of nonyellow snails, and of Arianta itself, respectfully. The last two columns indicate the frequency of yellow shells in the samples, and the proportion of buff shells among the brown snails.

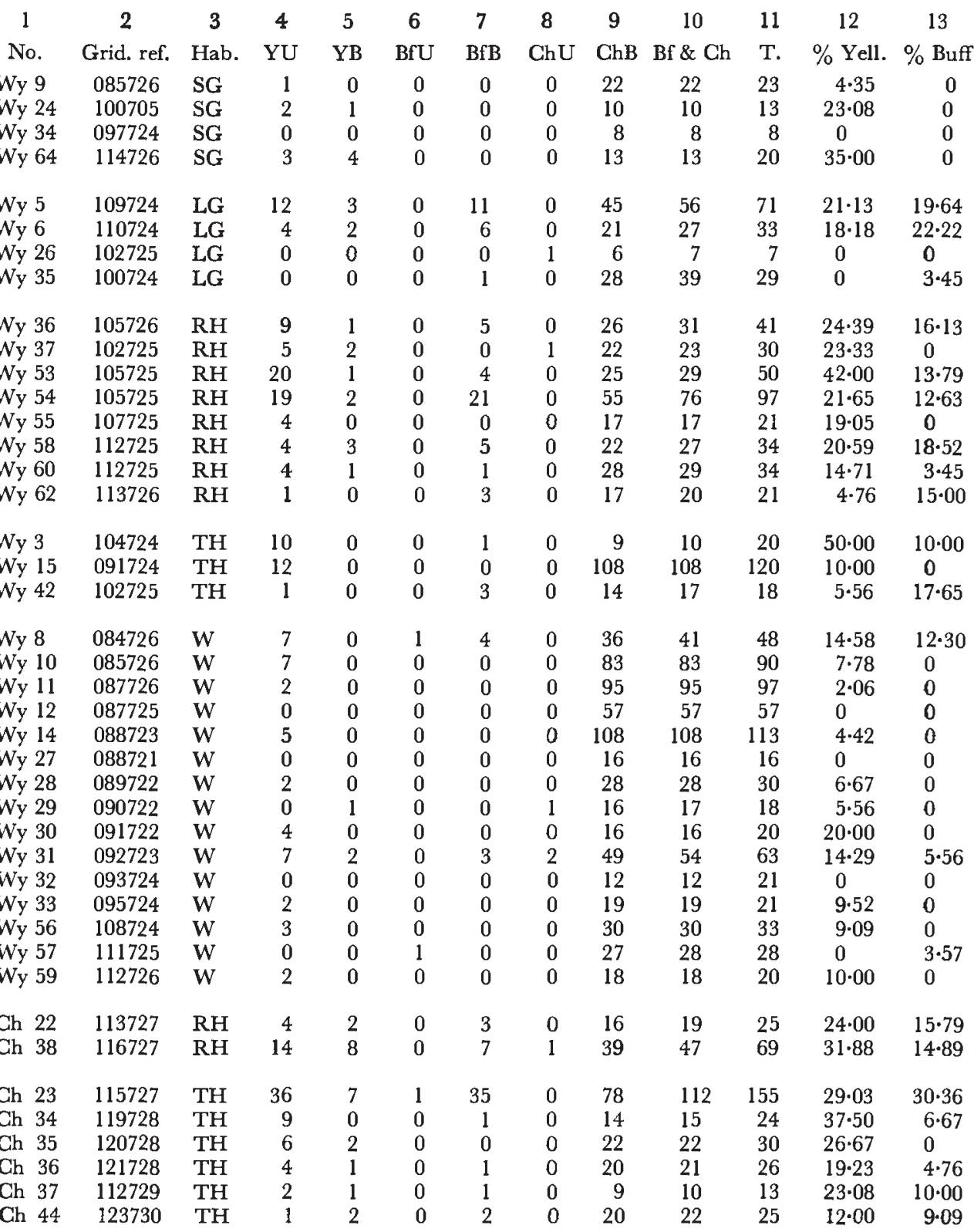


TABLE 1 -cont.

$\begin{array}{lllllllllllll}1 & 2 & 3 & 4 & 5 & 6 & 7 & 8 & 9 & 10 & 11 & 12 & 13\end{array}$

No. Grid. ref. Hab. YU YB BfB BfU ChU ChB Bf \& Ch T. \% Yell. \% Buff $\begin{array}{lllllllllllll}\text { Ch } 26 & 124734 & \text { W } & 1 & 1 & 0 & 0 & 0 & 31 & 31 & 33 & 6.06 & 0\end{array}$ $\begin{array}{lllllllllllll}\text { Ch } 27 & 126734 & \text { W } & 1 & 0 & 1 & 1 & 0 & 23 & 25 & 26 & 3.85 & 8.00\end{array}$ $\begin{array}{lllllllllllll}\text { Ch } 32 & 122732 & \mathrm{~W} & 1 & 0 & 0 & 0 & 0 & 17 & 17 & 18 & 5.56 & 0\end{array}$ $\begin{array}{rrrrrrrrrrrrr}\text { Ch } 33 & 118727 & \text { W } & 3 & 1 & 0 & 1 & 0 & 20 & 21 & 25 & 16 \cdot 00 & 4 \cdot 76 \\ \text { Ch } 39 & 122735 & \text { W } & 0 & 0 & 0 & 0 & 0 & 9 & 9 & 9 & 0 & 0\end{array}$ $\begin{array}{llllllllrrrrl}\text { Ch } 39 & 122735 & \text { W } & 0 & 0 & 0 & 0 & 0 & 9 & 9 & 9 & 0 & 0 \\ \text { Ch } 40 & 122735 & \text { W } & 1 & 0 & 0 & 1 & 0 & 21 & 22 & 23 & 4 \cdot 35 & 4.55\end{array}$ $\begin{array}{lllllllllllll}\text { Ch } 41 & 122733 & \text { W } & 1 & 0 & 0 & 0 & 0 & 13 & 13 & 14 & 7 \cdot 14 & 0\end{array}$

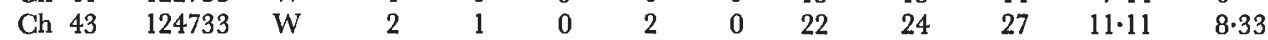

$\begin{array}{lllllllllllll}\text { Mi } 12 & 139731 & \text { SG } & 4 & 0 & 0 & 2 & 0 & 1 & 3 & 7 & 57 \cdot 14 & 66 \cdot 67\end{array}$ $\begin{array}{lllllllllllll}\text { Mi } 13 & 143732 & \text { SG } & 4 & 8 & 1 & 7 & 0 & 30 & 38 & 50 & 24 \cdot 00 & 21 \cdot 05\end{array}$

$\begin{array}{lllllllllllll}\text { Mi } 16 & 150733 & \text { LG } & 4 & 0 & 0 & 0 & 0 & 15 & 15 & 19 & 21.05 & 0\end{array}$

$\begin{array}{lllllllllllll}\text { Mi } 2 & 135733 & \text { RH } & 1 & 0 & 0 & 0 & 0 & 7 & 7 & 8 & 12.50 & 0\end{array}$

\begin{tabular}{|c|c|c|c|c|c|c|c|c|c|c|c|c|}
\hline Mi 1 & 137733 & $\mathrm{TH}$ & 0 & 0 & 0 & 0 & 0 & 6 & 6 & 6 & 0 & 0 \\
\hline Mi 10 & 129733 & $\mathrm{TH}$ & 7 & 0 & 0 & 0 & 0 & 1 & 1 & 8 & $87 \cdot 50$ & 0 \\
\hline Mi 14 & 145732 & $\mathrm{TH}$ & 6 & 4 & 3 & 0 & 0 & 42 & 45 & 55 & $18 \cdot 18$ & $6 \cdot 67$ \\
\hline Mi 23 & 144735 & TH & 8 & 3 & 0 & 2 & 0 & 17 & 19 & 30 & $36 \cdot 67$ & $10 \cdot 53$ \\
\hline Mi 24 & 162729 & $\mathrm{TH}$ & 13 & 0 & 0 & 0 & 0 & 27 & 27 & 40 & $32 \cdot 50$ & 0 \\
\hline Mi 25 & 165731 & $\mathrm{TH}$ & 2 & 0 & 0 & 1 & 0 & 3 & 4 & 6 & 33.33 & $25 \cdot 00$ \\
\hline Mi 27 & 166728 & $\mathrm{TH}$ & 5 & 0 & 0 & 1 & 0 & 13 & 14 & 19 & $26 \cdot 32$ & $7 \cdot 14$ \\
\hline Mi 28 & 169727 & TH & 3 & 1 & 0 & 0 & 0 & 14 & 14 & 18 & $22 \cdot 22$ & 0 \\
\hline $\mathrm{Mi}$ & 134733 & W & 1 & 0 & 0 & U & 0 & 14 & 14 & 15 & $6 \cdot 67$ & 0 \\
\hline Mi 11 & 135733 & W & 2 & 0 & 0 & 0 & 0 & 17 & 17 & 19 & $10 \cdot 53$ & 0 \\
\hline Mi 2 & 167731 & W & 1 & 2 & 0 & 0 & 0 & 33 & 33 & 36 & $8 \cdot 33$ & 0 \\
\hline Mi 22 & 167727 & W & 0 & 0 & 0 & 1 & 0 & 20 & 21 & 21 & 0 & $4 \cdot 55$ \\
\hline
\end{tabular}

$\begin{array}{lllllllllllll}\text { Mo } 24 & 180712 & \text { RH } & 4 & 0 & 0 & 1 & 0 & 44 & 45 & 49 & 8.16 & 2 \cdot 22\end{array}$

$\begin{array}{lllllllllllll}\text { Mo } 33 & 176701 & \text { RH } & 1 & 1 & 0 & 3 & 0 & 26 & 29 & 31 & 6.45 & 10 \cdot 34\end{array}$

$\begin{array}{lllllllllllll}\text { Mo } 35 & 168702 & \text { RH } & 2 & 1 & 0 & 4 & 0 & 28 & 32 & 35 & 8.57 & 12.50\end{array}$

$\begin{array}{lllllllllllll}\text { Mo } 11 & 183717 & \mathrm{TH} & 1 & 0 & 0 & 3 & 0 & 11 & 14 & 15 & 6.67 & 21.43\end{array}$

$\begin{array}{lllllllllllll}\text { Mo } 34 & 178700 & \text { TH } & 1 & 1 & 0 & 5 & 0 & 19 & 24 & 26 & 7 \cdot 69 & 20 \cdot 83 \\ \text { Mo } 45 & 182697 & \text { TH } & 2 & 0 & 0 & 5 & 0 & 24 & 29 & 31 & 6.45 & 17 \cdot 24\end{array}$

$\begin{array}{lllllllllllll}\text { Mo } 10 & 185715 & \text { W } & 2 & 0 & 0 & 3 & 0 & 23 & 26 & 28 & 7 \cdot 14 & 11.54\end{array}$

$\begin{array}{lllllllllllll}\text { Mo } 13 & 176723 & \text { W } & 0 & 1 & 0 & 0 & 0 & 40 & 40 & 41 & 2.44 & 0\end{array}$

$\begin{array}{lllllllllllll}\text { Mo } 31 & 172702 & \text { W } & 3 & 0 & 0 & 0 & 0 & 24 & 24 & 27 & 11 \cdot 11 & 0\end{array}$

$\begin{array}{lllllllllllll}\text { Mo } 32 & 173702 & \text { W } & 2 & 0 & 0 & 1 & 1 & 41 & 43 & 45 & 4.44 & 2.33\end{array}$

$\begin{array}{lllllllllllll}\text { Mo } 39 & 190695 & \text { W } & 0 & 0 & 0 & 0 & 0 & 18 & 18 & 18 & 0 & 0\end{array}$

$\begin{array}{rrllllllrrrrc}\text { Mo 43 } & 180696 & \text { W } & 0 & 0 & 0 & 0 & 1 & 8 & 9 & 9 & 0 & 0 \\ \text { Mo 44 } & 181696 & \text { W } & 0 & 0 & 0 & 2 & 0 & 11 & 13 & 13 & 0 & 15 \cdot 38\end{array}$

$\begin{array}{rrrrrrrrrrrrr}\text { Mo 44 } & 181696 & \text { W } & 0 & 0 & 0 & 2 & 0 & 11 & 13 & 13 & 0 & 15 \cdot 38 \\ \text { Mo 46 } & 184696 & \text { W } & 0 & 0 & 0 & 1 & 0 & 29 & 30 & 30 & 0 & 3 \cdot 33\end{array}$

$\begin{array}{lllllllllllll}\text { Ma } 3 & 282594 & \text { LG } & 3 & 0 & - & - & 0 & 9 & - & 12 & 25.0\end{array}$

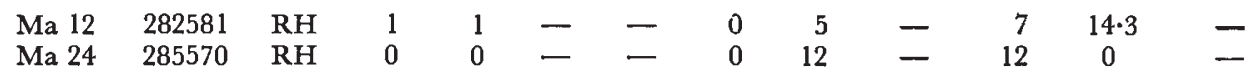

$\begin{array}{lllrlllllllll}\text { Ma 9 } & 284577 & \text { TH } & 5 & 0 & - & - & 0 & 34 & - & 39 & 12 \cdot 8 & \text { - } \\ \text { Ma } 13 & 286582 & \text { TH } & 14 & 1 & - & - & 0 & 21 & - & 36 & 38.9 & -\end{array}$

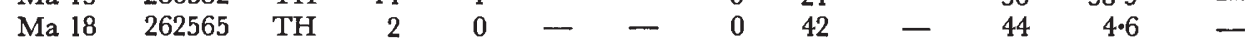

$\begin{array}{lllllllllllll}\text { Ma } 8 & 283537 & \text { W } & 0 & 0 & - & - & 0 & 38 & - & 38 & 0 & - \\ \text { Ma } 11 & 289574 & \text { W } & 0 & 0 & - & - & 0 & 25 & & 25 & 0 & -\end{array}$ 


\begin{tabular}{ccccccccccccc}
\multicolumn{10}{c}{ TABLE 1-cont. } \\
1 & 2 & 3 & 4 & 5 & 6 & 7 & 8 & 9 & 10 & 11 & 12 & 13 \\
No. & Grid ref. & Hab. & YU & YB & BfU & BfB & ChU & ChB & Bf \& Ch & T. & $\%$ Yell. & \\
Ma 14 & 273570 & W & 1 & 0 & - & - & 0 & 24 & - & 25 & 4.0 & - \\
Ma 15 & 270569 & W & 0 & 0 & - & - & 0 & 9 & - & 9 & 0 & - \\
Ma 17 & 275572 & W & 3 & 0 & - & - & 0 & 40 & - & 43 & $7 \cdot 0$ & - \\
Ma 19 & 269566 & W & 0 & 0 & - & - & 0 & 11 & - & 11 & 0 & - \\
Ma 20 & 277573 & W & 0 & 0 & - & - & 0 & 6 & - & 6 & 0 & - \\
Ma 21 & 279754 & W & 0 & 0 & - & - & 0 & 41 & - & 41 & 0 & - \\
Ma 22 & 282574 & W & 0 & 0 & - & - & 0 & 18 & - & 18 & 0 & - \\
Ma 23 & 265565 & W & 0 & 0 & - & - & 0 & 8 & - & 8 & 0 & - \\
Ma 30 & 297590 & W & 0 & 0 & - & - & 0 & 8 & - & 8 & 0 & -
\end{tabular}

illustrates the composition of two samples chosen merely because they contain large numbers of snails. The genetics of buff is not known, but it is possible that it could be the heterozygote between yellow and brown. Cook and King (1966), however, consider dominance to be complete, and the data of table 2 support this since buffs are significantly fewer than would be expected from the Hardy-Weinberg equilibrium $(P<0.001)$.

TABLE 2

The composition of two samples of $\mathrm{A}$. arbustorum from the valley of the river Wye

\begin{tabular}{|c|c|c|c|c|c|c|}
\hline & \multicolumn{3}{|c|}{ Wydale 54} & \multicolumn{3}{|c|}{ Cheedale 23} \\
\hline & Unbanded & Banded & Total & Unbanded & Banded & Total \\
\hline Yellow & 19 & 2 & 21 & 36 & 7 & 43 \\
\hline Buff & 0 & 21 & 21 & 1 & 33 & 34 \\
\hline Chocolate & 0 & 55 & 55 & 0 & 78 & 78 \\
\hline Total & 19 & 78 & 97 & 37 & 118 & 155 \\
\hline
\end{tabular}

There is no discernible difference in the proportion of unbanded between buff and chocolate, and this is typical of the data as a whole. They differ markedly from yellow in being associated with the banded condition. The continuous variation in brown could result from a series of modifiers adjusting the expression of the major gene.

\section{Correlation with baGkground}

(a) Distribution of yellow

The woods in Derbyshire are primarily Ash, and for a considerable part of the year the ground below the trees is bare or covered with a carpet of leaf litter from the previous season. This gives a brownish background even in the areas where Dog's Mercury grows, for little grows between these plants. The grassland and other non-woodland habitats are green for much of the year, more so than in areas away from limestone. The change in colour during the winter months is to a dull straw, and the background is still paler than the adjacent woodland.

The proportion of yellow-shelled individuals in the series of samples from woodland has been compared with that from the non-woodland habitats in the same dale, using the U-test (Mann and Whitney, 1948). The results of these comparisons are shown in table 3 , where the observed values of $U$ are laid out beside the expected values, with the latter's variance. The value of $\mathrm{P}$ reflects the probability of there being no difference between the 
frequency of yellow in the woodland and non-woodland habitats of the dale under consideration. The 17 samples from the area around Matlock, which lies about 9 miles to the east of Bakewell, can also be included here. The shells in these collections are too faded to permit accurate scoring for the shade of brown, so the columns in table 1 listing the number of buff shells have been left blank. There are 11 woodland and 6 non-woodland samples and, as shown in table 3, there is a significant excess of yellow shells in the non-woodland samples. Yellow snails are significantly more common in the non-woodland samples than in the woodland collections from the same dale.

TABLE 3

A comparison of the frequency of yellow and pale brown individuals in samples of Arianta arbustorum taken from woodland and non-woodland

(a) Yellow

(b) Buff in brown

$\begin{array}{lrrc} & \text { Obs. U. } & \text { Exp. U. } & \text { P. } \\ \text { Wyedale } & 73.0 & 142.5 & 0.02 \\ \text { Cheedale } & 1.0 & 32.0 & 0.01 \\ \text { Millersdale } & 3.5 & 24 \cdot 0 & 0.01 \\ \text { Monsaldale } & 9 \cdot 0 & 24 \cdot 0 & 0.03 \\ \text { Matlock } & 7.5 & 33.0 & 0.01 \\ & & & \\ \text { Wyedale } & 79 \cdot 0 & 142.5 & 0.02 \\ \text { Cheedale } & 10.5 & 32.0 & 0.02 \\ \text { Millersdale } & 15 \cdot 0 & 24 \cdot 0 & 0.28 \\ \text { Monsaldale } & 7.0 & 24.0 & 0.02\end{array}$

This result is comparable with the findings of the workers referred to earlier, who showed that yellow unbanded $C$. nemoralis and "effectively yellow" (Clarke, 1962) C. hortensis were at an advantage on green backgrounds, and dark snails-whether pink, brown or with fused bands-were favoured in woods.

\section{(b) Distribution of buff}

If visual selection is the cause of the difference in the proportions of yellow individuals in the populations, buff shells should be advantageous in localities where yellows are favoured. Conversely, on the dark brown background of woodland floors, chocolate would be favoured at the expense of buff.

Table 3 shows the results of comparing the frequency of buff in the brown shells from the series of samples from the two habitat types in each dale. The samples from Matlock have been omitted since it was not possible to score them accurately for the shade of brown. There are significant differences for Wyedale, Cheedale and Monsaldale, but for Millersdale there is a 28 per cent. probability that the result is due to chance. The four results are effectively separate experiments and as they are all in the same direction (namely, more buffs in non-woodland habitats) the method of Fisher (1950) can be used to combine the probabilities. This gives $\chi^{2}$ of 25.8 with 8 degrees of freedom, which is significant at the l per cent. level. There can therefore be little doubt that buff-shelled Arianta are more abundant in populations from non-woodland localities than woodland ones.

\section{(c) Analysis of predated material}

Morris (1952) showed that it is possible to distinguish thrush-broken Cepaea shells from those broken by rodents. The two predators produce 
differences in the position and nature of the fracture of the spire. The shell of Arianta is sometimes thin and fragile so that it collapses when assailed, rendering identification of the predator difficult. For this reason, shells are merely recorded as " predated in the present section ". Some other samples can be added. Two are from woodland localities around Bakewell. Arianta was absent from the non-woodland habitats examined in this part of Derbyshire. The other additional samples are from woodland habitats in the mouths of some side-dales of the main valley of the river Wye.

Scoring each sample separately for the number of yellow and brown individuals which had been killed by predators, or not, yields data which can be examined directly for evidence of differential selection. Using Cochran's (1954) method for combining a series of contingency tables using weighted differences in proportion gives no evidence of yellows being selectively predated in woodlands $(P \bumpeq 0 \cdot 25)$.

There is considerable heterogeneity between samples from similar habitat within some of the dales, so that data from the separate samples perhaps should not be combined. However, the number of each colour morph taken by predators from a population will be the combined results of a series of factors. Firstly, birds search entirely visually, whereas mammals may use their sense of smell to locate a snail. The former will therefore predate selectively, the latter may not, and no attempt has been made to distinguish between these types of predation. Secondly, differences in the relative proportions of snail-eating birds and mammals will result in differences in proportions taken. Thirdly, Allen and Clarke (1968) have shown that birds have colour preferences, and search images become superimposed upon these. Separate birds will have different preferences and images, resulting in variations in the proportion of yellows taken in separate localities. Finally, the background, while falling clearly into "woodland" or "non-woodland" will vary in colour, giving different backgrounds. These will all combine and interact to give differences in the proportion of yellow and brown available and taken, and consequently the heterogeneity between sites is not too disturbing.

Bearing this in mind, the samples from woodland and non-woodland habitats have been combined for each dale into table 4 . The unpredated shells include both live individuals and unbroken dead shells: there is no difference in the proportion of yellow between these two classes. A higher proportion of yellow than brown shells have been predated in woodland. In non-woodland, the converse holds and brown are more heavily predated except among the populations around Matlock. Sheppard (1951) found that as the season progressed and the background of a wood became greener, so the Song Thrushes took a progressively higher proportion of pink $C$. nemoralis compared with yellow. The present result where yellow shells are at a greater disadvantage in woodland, and a lesser in non-woodland, is a significant one $(\mathrm{P}<0.01-$ one tailed sign test $)$ and agrees with that of Sheppard.

\section{Discussion}

The principal predators of Arianta involved in the present analysis are probably Song Thrushes, which hunt visually, and small mammals which possibly find their prey by scent rather than by sight. Predation appears to be a far more important cause of death in woodland, for the proportion of 


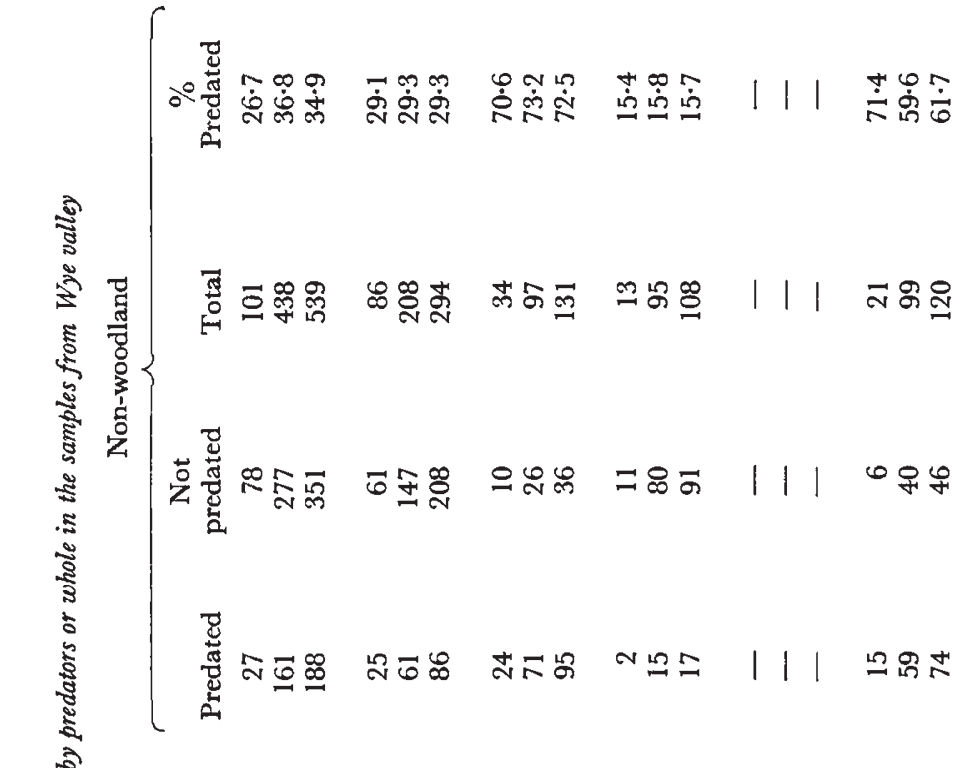

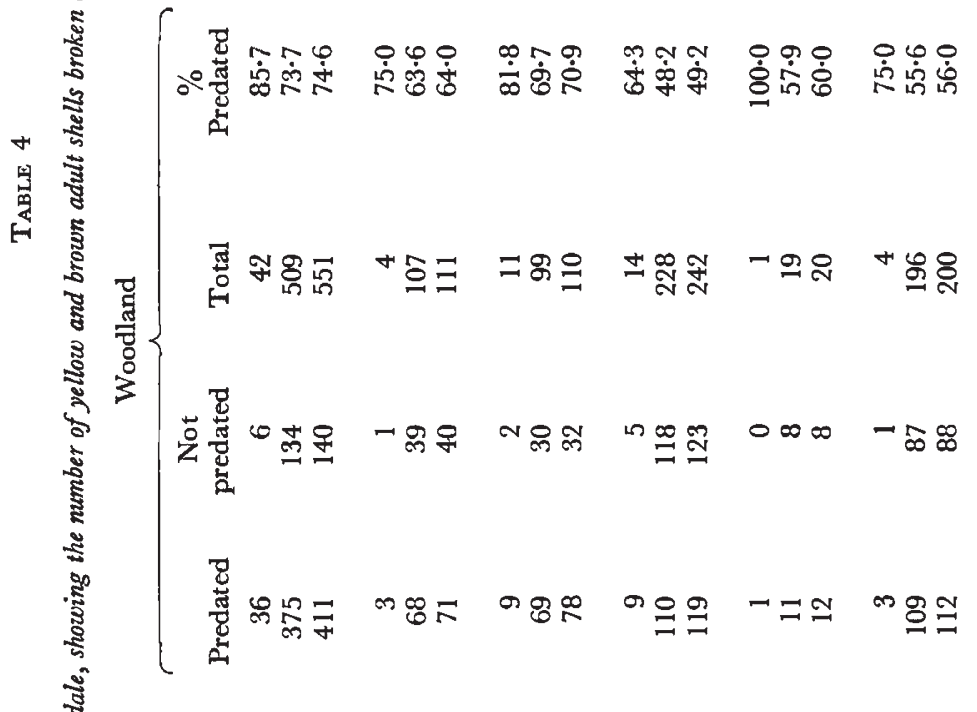

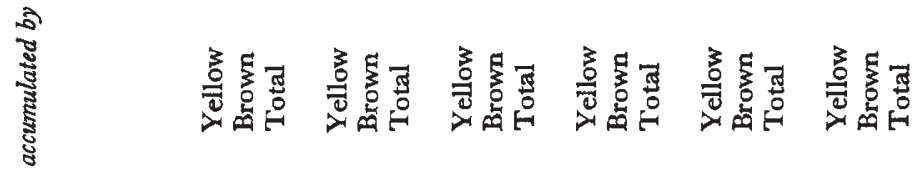

$$
\begin{aligned}
& \text { ฐั้ }
\end{aligned}
$$




predated shells is higher in this habitat. This is also the opinion of Greenwood and Pedder (in prep.) who have undertaken a similar survey of Cepaea spp. in the same area. They were able to distinguish between thrush and rodent predation in their material, and considered both to be higher in woodland habitats, but rodents slightly less so than thrushes.

Cain (1953) has presented evidence that rabbits (Oryctolagus cuniculus L.), as colour-blind mammals, predate selectively by visual tone, and favour pink rather than yellow $C$. nemoralis on short downland turf. This has also been shown by Murray (1962) for " rodents". There were very few rabbits in the area of the Wye valley covered by the present survey during 1964-67, so that species can probably be ruled out as an important predator of presentday populations of Arianta. However, should other species of small mammals use vision rather than scent, they would probably show similar discrimination. Under such circumstances, yellow (i.e. pale) individuals would still be at a selective disadvantage in woodland. In greener habitats the brown morphs might be cryptic under some situations such as in the bottom of tufts of grass and in shady corners, so the selective differential would be less marked.

This expectation is partially borne out in the results reported above, for the proportion of yellow shells is higher in the predated than the non-predated material in all six sets of woodland data. In that from non-woodland, there is one area where brown shells are less predated than yellow, and the proportions of the two colour classes which have been predated are more similar than in woodlands.

Visual selection for crypsis will be operative wherever predators take snails after seeking them out by eye. The effects will depend upon the intensity of other selective forces. Thus, over large areas of Britain, populations of $C$. nemoralis exhibit area effects (Cain and Currey, 1963) where the frequency of a particular colour or banding variety is high or low over a wide area compared with the panmictic unit, and despite changes in habitat. Carter (1967) has shown that even here fluctuations may occur in the shade of shell colour, varying with habitat within a single area effect. He also showed (1967) that, where one factor was invariable within the confines of an area effect, other factors might vary in a manner consistent with visual selection.

Cain and Currey (1968) have shown that when the Song Thrushes were all killed by a severe winter, some morph frequencies of $C$. nemoralis in a grassland population within an area effect changed towards those in an adjacent nettle patch where predation had consisted of non-visual removal of buried snails in winter, and the removal of individuals from the periphery in summer when the confines were too dense for the birds to penetrate. The apparently simpler polymorphism of Arianta renders the detection of area effects more difficult, and of visual selection more easy than in $C$. nemoralis. In this part of Derbyshire, $C$. nemoralis appears to be varying between complex area effects with a superimposition of visual selection upon some of them (Greenwood, pers. comm.).

Since the yellow variety remains in the woodland populations despite this selection against it, it must be favoured at some stage of the life-cycle. Cook and King (1966) found no evidence of mutation occurring at the colour or banding loci, so mutation pressure is unlikely. The yellow variety could be held in the population by some form of environmental selection. This has been postulated for Cepaea by Lamotte (1951), Arnold (1968) and 
Cameron (1968) among others and associations between the occurrence of unbanded yellow Arianta and areas of high rainfall in northern and western Scotland have been shown by Cain, Cameron and Parkin (1969). Similar effects can be detected within Britain as a whole as well as in the area covered by the present paper (Parkin, in prep.).

A further force which has been postulated as capable of maintaining the frequencies of the shell-character genes of molluscs is frequency-dependent visual selection or apostatic selection (Clarke, 1962). If a predator is able to develop a specific search image for a particular morph, it might miss differently coloured or patterned members of the same species during its search for food. This situation might occur in Arianta. The yellow unbanded form is totally distinct from banded brown, and apostatic selection could operate to maintain the yellow variety in woodland. It is difficult to show this type of selection in natural populations, and the data from Derbyshire are not adequate for investigating this matter.

\section{Summary}

1. Arianta arbustorum, a British land snail, is polymorphic for colour and banding. The banded condition is usually associated with brown shell colour; unbanded individuals are yellow. There is variation in the shade of brown from pale to dark.

2. Among populations of $A$. arbustorum inhabiting the Wye valley in Derbyshire, yellow individuals are common in non-woodlands. Pale brown shelled snails are similarly commoner than dark brown in non-woodlands. Dark brown is the predominant form in woodland areas.

3. The frequency of predated shells within a colour class shows a higher proportion among the yellow shells than the browns in woodland. The converse is found in non-woodland habitats for four of the five areas considered.

4. It is argued that visually discriminating predators are selectively removing yellow snails from the woodland populations, resulting in the differences in distribution of the morphs found in the two habitat classes.

5. The results are compared with those obtained in studies of Cepaea nemoralis and $C$. hortensis and their significance discussed.

Acknowledgments. - The field work which forms the basis of this paper was undertaken in collaboration with Dr R. A. D. Cameron and Mr J. J. D. Greenwood, and I am grateful to them for much stimulating discussion at all stages of the study. The work was carried out in the Department of Zoology at the University of Manchester during the tenure of a Science Research Council studentship. I am grateful to Professors A. J. Cain and R. Dennell for the facilities which they provided. I am further grateful to Professor Cain for his supervision, advice and criticism. My wife assisted with the field work, and Dr B. C. Clarke and Mr J. S. Jones read and criticised the manuscript.

\section{REFERENCES}

Allen, J. A., AND GlaRke, B. C. 1968. Evidence for apostatic selection in wild passerines. Nature, 220, 501-502.

ARNOLD, R. W. 1965. Factors affecting gene-frequencies in British and Continental populations of Cepaea. D.Phil. Thesis, University of Oxford.

ARnOLD, R. w. 1968. Studies on Cepeaa. VII. Climatic selection in Cepaea nemoralis (L.) in the Pyrenees. Phil. Trans. Roy. Soc. Lond., B. 253, 549-593. 
GAIN, A. J. 1953. Visual selection by tone of Cepaea nemoralis (L.). J. Conchology, 23, 333-336. CAIN, A. J., CAMERON, R. A. D., AND PARKIN, D. T. 1969. Ecology and variation of some Helicid snails in northern Scotland. Proc. Maloc. Soc. Lond.

CaIN, A. J., AND Currey, J. D. 1963. Area effects in Cepaea. Phil. Trans. Roy. Soc. Lond., B. $246,1-81$.

CAIN, A. J., AND CURREY, J. D. 1968. Studies on Cepaea. III. Ecogenetics of a population of Cepaea nemoralis (L.) subject to strong area effects. Phil. Trans. Roy. Soc. Lond., B. 253, 447-482.

CAIN, A. J., AND ShePPARD, P. M. 1950. Selection in the polymorphic land snail Cepaea nemoralis. Heredity, 4, 275-294.

CAIN, A. J., AND SHEPPARD, P. M. 1952. The effects of natural selection on body colour in the land snail Cepaea nemoralis. Heredity, 6, 217-231.

GaIn, A. J., AND ShePPARD, P. M. 1954. Natural selection in Cepaea. Genetics, 39, 89-116.

GAIN, A. J., SHEPPARD, P. M., AND KING, J. M. B. 1968. Studies on Cepaea. I. The genetics of some morphs and varieties of Cepaea nemoralis (L.). Phil. Trans. Roy. Soc. Lond., B. 253, 383-396.

CAMERON, R. A. D. 1968. The comparative scology of three closely related species of polymorphic land snail. Ph.D. Thesis, University of Manchester.

CARTer, M. A. 1965. An investigation of the area effect in Cepaea. D.Phil. Thesis, University of Oxford.

CARTER, M. A. 1967. Selection in mixed colonies of Cepaea nemoralis and Cepaea hortensis. Heredity, 22, 117-139.

CLARKE, B. C. 1962. Natural selection in mixed populations of two polymorphic snails. Heredity, 17, 319-365.

COCHRAN, w. G. 1954. Some methods for strengthening the common chi-squared test. Biometrics, 10, 417-451.

COOK, L. M., AND KING, J. M. B. 1966. Some data on the genetics of shell-character polymorphism in the snail Arianta arbustorum. Genetics, 53, 415-425.

CURREY, J. D., ARNOLD, R. W., AND CARTER, M. A. 1964. Further examples of variation of populations of Cepaea nemoralis with habitat. Evolution, 18, 111-117.

FISHER, R. A. 1950. Statistical Methods for Research Workers. Edinburgh: Oliver and Boyd. Goodhart, c. B. 1958. Thrush predation on the snail Cepaea hortensis. J. Anim. Ecol., 27, 47-57.

GREENWOOD, J. J. D., AND PEDDER, I. J. (in prep.).

LAмотTE, M. 1951. Recherches sur la structure genetique des populations naturelles de Cepaea nemoralis. Bull. Biol. (suppl.) 35, 1-239.

MANN, H. B., AND WHITNEY, D. R. 1947. On a test of whether one or two random variables is stochastically larger than the other. Ann. Math. Stat., 18, 50-60.

MORRIs, D. 1954. The snail-eating behaviour of thrushes and blackbirds. British Birds, 47, 33-49.

MURRAY, J. J. 1962. Factors affecting gene-frequencies in some populations of Cepaea. D.Phil. Thesis, University of Oxford.

oldham, c. 1934. Some albinistic varieties of Arianta arbustorum (L.). Proc. Maloc. Soc. London, 21, 103-108.

SHEPPARD, P. M. 1951. Fluctuations in the selective value of certain phenotypes in the polymorphic land snail Cepaea nemoralis (L.). Heredity, 5, 125-134.

SHEPPARD, P. M. 1952. Natural selection in two colonies of the polymorphic land snail Cepaea nemoralis. Heredity, 6, 233-238.

TAYLOR, J. w. 1914. Monograph of the Land and Freshwater Mollusca of the British Isles, Vol. 3. Leeds: Taylor. 